\title{
Local Community Participation in the Implementation of REDD+: The Case of Meru Betiri National Park
}

\author{
Pradipta Dirgantara \\ Department of Communication, School of Communication and Business, Telkom University, Indonesia \\ Email: pdirgantara@telkomuniversity.ac.id \\ Submitted: 31 January 2020; Revised: 28 October 2020; Accepted: 21 December 2020
}

\begin{abstract}
Abstrak
Reduksi Emisi dari Deforestasi dan Degradasi Hutan dan Lahan Gambut (REDD+) di Taman Nasional Meru Betiri (TNMB) merupakan program kolaborasi antara pemerintah Indonesia, International Tropical Timber Organization (ITTO), dan komunitas lokal yang dinilai penting secara global untuk memitigasi perubahan iklim dan pemanasan global. Dalam implementasinya, partisipasi komunitas berperan besar dalam REDD + sesuai dengan deklarasi Anchorage. Penelitian ini bertujuan untuk mengetahui level partisipasi dalam implementasi REDD+ di TNMB. Penelitian ini menggunakan metode campuran kualitatif - kuantitatif dengan strategi studi kasus. Data dikumpulkan melalui penyebaran kuesioner, wawancara semi-terstruktur, dan studi literatur. Hasil penelitian menunjukan bahwa tingkatan partisipasi merujuk pada konsiliasi yang berarti dalam tahapan awal dukungan komunitas dan penyelenggara yang sadar kepentingan masing-masing. Meskipun demikian pemerintah memiliki wewenang besar dalam mendorong pembuatan keputusan yang partisipatoris dalam REDD +. Pemerintah beserta pemangku kepentingan dalam skala lokal dan nasional perlu mengakselerasi partisipasi komunitas melalui penegakan hukum dan pelibatan komunitas secara penuh dalam implementasi REDD+.
\end{abstract}

Kata Kunci : REDD+, komunitas lokal, partisipasi, perdagangan karbon, pemanasan global.

\begin{abstract}
Reducing Emissions from Deforestation and Forest Degradation Plus (REDD+) in Meru Betiri National Park (MBNP) East Java - Indonesia, is considered an essential collaborative program between the Indonesian government, International Tropical Timber Organization (ITTO), and surrounding local communities to mitigate climate change and global warming. In its implementation, community participation plays a significant role because they are impacted directly by REDD+, as stated in the Cancun Agreement and Anchorage Declaration of Indigenous Peoples on Climate Change. Therefore, this research focuses on the participation level and how it contributes to the program. This research used the community participation theory from Choguill and benefited from using mixed methods with a single case strategy. Data were gathered through a questionnaire, a semi-structured interview, and a literature study. The results uncovered that the participation level reached conciliation with the least support of three rungs as a degree of participation. At this stage, the local community and government started to realize their interests by supporting each other. Even so, the government had control in enforcing the decision-making process that involved the community in REDD + . In the end, government and stakeholders at the local and national scales should accelerate community participation through law enforcement and full community involvement in implementing REDD+.

Keywords: REDD+, local community, participation, carbon trade, global warming
\end{abstract}

\section{INTRODUCTION}

Implementing REDD+ in Indonesia aims to reduce emissions by 29 percent of the development through business scenarios in 2030 with its funds without compromising development in other sectors, or 41 percent with international funding assistance. The scope of REDD+ has become a broad mechanism that can be applied to all Indonesia's forests, including

mangrove forests. However, it is complicated by the politics and people involved. It entangles governance, the rights of local communities, volatile global carbon prices, the complexities of carbon accounting and the challenges of monitoring feature in the convoluted REDD+ landscape (Askham, 2010). It also involves multi-actors and sometimes from private sectors. 
REDD+ can attract private investment, but investors need to cooperate with state agencies and local people (Forsyth, 2009).

To obtain success in REDD+, the full and effective participation of the local community and indigenous people are significantly needed (Lyster, 2013). According to the Cancun Agreement, their participation is stated necessary for effective action on all aspects of climate change (UNFCCC, 2010). The 2009 Anchorage Declaration of Indigenous People on Climate Change points out the right of indigenous people and local communities to conserve and access forest products.

In Indonesia, REDD+ pilot projects mostly occur in Sumatra and Kalimantan since both islands have the largest forested area. Between 2000 and 2010, the land cover of forested areas in Sumatra had decreased 2.7\% each year, the biggest in Indonesia, followed by Kalimantan, which had decreased $1.3 \%$ each year (Miettinen, Shi, \& Liew, 2011). Based on this history, the deforestation rate is estimated at around 1.125 million hectares per year, in which 0.626 million hectares of it is caused by illegal logging (BAPPENAS, 2010). Other data state that the forest stock in Indonesia decreases by a rate of $6 \%$ a year, of which one-third are due to deforestation (Marklund \& Schoene, 2006).

Following this urgency, there are 44 REDD+ pilot projects underway throughout Indonesia. The projects use different afforestation/reforestation strategies, avoided deforestation, avoided degradation, and restoration. CIFOR (2010) classified the pilot projects activities that directly aim to reduce emissions from deforestation and forest degradation in the different geological areas to be recognized by the stakeholders as REDD+ activities and operate within an official agreement with the government a certain level.

The Meru Betiri National Park (MBNP), located in Jember and Banywangi - East Java, has become one of the REDD+ pilot projects in Indonesia since 2010, with the duration of the project initially from 2010-2014 (48 months) and extended to the first semester of 2015. Even though the project has officially ended, the evaluation and monitoring stage to the date of this research is still ongoing.

MBNP is considered home for plants and animals and for people whose livings are inextricably linked to the forest ecosystem. People living close to MBNP and MBNP are largely dependent on forestry activities for a long time. Their need for forest products for food, fodder, agriculture, and housing, can potentially degrade forest if harvested unsustainably. One of the consequences of the implementation of REDD+ in MBNP is that forest activities become more stringent. Therefore, the livelihoods of forest-dependent people are at stake, and without their participation and collaboration, the success of the REDD+ implementation in MBNP is difficult to achieve. Hence, it is essential to research the local community participation in MBNP as a mitigation endeavor to reduce carbon emissions through the REDD+ framework and acknowledge that the local community participation in the REDD+ process is crucial.

REDD+ in MBNP is the only Demonstrated Activities (DA) project on the island of Java, which has been implemented $100 \%$ inside the conservation area of the park and aims to deliver a tropical forest conservation plan as part of REDD+ initiatives. REDD+ in MBNP was run under a public-private partnership from the Indonesian Ministry of Forestry and the International Tropical Timber Organization (ITTO) with financing from 7 \& i Holdings Ltd (Japan). ITTO pledged to contribute US $\$ 814,590$, and Indonesia pledged to contribute US\$ 158,798 (ITTO, 2009). In 2011, MBNP succeeded in setting its carbon baseline with a total of 29,690,954.3 tCO2e.

One of the mandates in REDD+ is that it should reflect efforts to reduce emissions and the growing initiatives on conserving and enhancing forests with their values and secluding the local community. This mandate was mentioned in the Bali Action Plan and the Copenhagen Accord with another important mandate under a public-private partnership, the implementation of REDD+ in Indonesia is expected to get accelerated to achieve general objectives. One of the specific objectives of the implementation of REDD+ in 
MBNP is to improve the livelihood of the local community living inside and in the surrounding the MBNP through full participation in avoiding deforestation, degradation, and biodiversity loss.

The involvement of the local community and indigenous people is essential in the success of the REDD+ implementation. The government solely representing them in the REDD+ implementation is inadequate since REDD+ must involve all stakeholders to succeed, including the local community and indigenous people. Many pilot projects in Indonesia have been launched to reach the local community and indigenous people living in the forests. According to the Ministry of Forestry, there have been 44 REDD+ projects in Indonesia since 2010 (Ministry of Forestry of the Republic of Indonesia, 2011), and only one REDD+ project (REDD+ Central Kalimantan) follows the Guidelines of REDD+ SES, involving three core elements: governance, interpretation, and assessment.

MBNP is the only forest with a REDD+ pilot project in Java. Specifically located in East Java under the administrative of Banyuwangi and Jember, REDD+ in MBNP was funded around $80 \%$ from ITTO. Initially, the duration of the project is three years from 2010 to 2013. However, it has been extended to 2016. There are more than five villages nearby directly influenced by REDD+. Two villages are located inside the area of MBNP. There is no prior research attempting to dive into their participation. Noticing that their participation is essential, the study of the local community participation in the REDD+ implementation in MBNP is needed to reduce emissions from deforestation and forest degradation. Therefore, the objective of the research is to identify the local community participation in the REDD+ implementation.

\section{LITERATURE REVIEW}

Many studies focusing on REDD+ have been conducted. Those studies are related to various perspectives from law, economics, ecology, social, and politics. Erbaugh et al. (2017) analyzed forest legality verification through Forest Law Enforcement, Governance, and Trade (FLEGT) in Central Java,
Indonesia. The results showed that forest legality has enforced regulatory changes affecting pre-existing policies and practices within timber production networks. Lubowski and Rose (2013) discussed REDD+ in a more specific economic framework to elaborate the costs required to bring together sellers and buyers of environmental services in REDD transaction costs. Ekawati et al. (2019) examined policy structures and the behavior of actors within and outside the forestry sector affecting the preparation of REDD+ implementation in Papua, Central Kalimantan and Riau. From an ecological perspective, Alexander (2011) elaborated research focusing on REDD+ potential as an ecological restoration that contributes to climate change mitigation, sustainable management, and increasing carbon stocks.

The implementation of REDD+ has triggered many research questions. Casse et al. (2019) highlighted the social challenges of the readiness and implementation of REDD+ proven running slow and fallen short of expectations in Indonesia and Vietnam, focusing on the readiness phase, examining policy processes at the central, provincial and local levels. From a political perspective, Hein (2019) analyzed transnational agrarian conflicts that have substantial implications for global environmental justice in the REDD+ pilot province of Jambi on the island of Sumatra on an innovative conceptual approach linking political ecology, politics of scale and theories of power.

Moreover, Enrici and Hubacek (2018) presented the results of a case study of three REDD+ project sites to identify essential criteria at the root of success or failure through several indicators such as finance, community, boundary enforcement, monitoring, and outcomes of attempted carbon sequestration and biodiversity preservation.

Among many research related to REDD+, a few took the local community as its main topic. They mostly revolved around the legal framework and institutionalization process, such as the right of the local community, indigenous people, and their livelihood impacted by REDD+ without considering their participation. Bong et al. (2016) elaborated on the possibility of local participation in REDD+. However, 
this possibility faced various challenges, especially at the project level, where MRV capacity and readiness were low. Even though Indonesia is considered one of the REDD+ participant countries with good quantitative data on drivers at the national scale, it has no explicit linkage to deforestation and forest degradation.

On the other hand, Boissière et al. (2017) argued that local participation in REDD+ is desirable but uncertain. To increase its certainty, there is a need to enforce participatory MRV (PMRV) that involves local communities and other local actors. It is also elaborated that local communities can play a significant role in REDD+ by building a strong system, such as assessing past experiences and costs.

Awono et al. (2011) stated that land tenure ambiguity should be resolved, and local participation was ensured in the East and South regions of Cameroon. Payments for Ecosystem Services (PES) was integrated into community forest management where two villages had agreed to accept conditional payment to increase carbon stocks instead of deforesting and degrading forest. In Eastern Brazilian Amazon, Cromberg et al. (2014) researched local participation in the Eastern Brazilian Amazon through four community focus groups and 137 household interviews. It resulted in the need for participation that went beyond passive consultation with local people in REDD+. Therefore, local participation in REDD+ can facilitate the development of interventions that best reflect local knowledge, land-use practices, and aspirations.

To demonstrate the success of REDD+, it is necessary to study the participation of indigenous people and the local community in the implementation of REDD+, especially in MBNP. Even though many studies on local community participation in REDD+ have been carried out, no research is conducted explicitly on local participation in MBNP. Therefore, this research ensures the participation level of the local community in the implementation REDD+ scheme as they are dependent on the forest, and their involvement is crucially needed to bring social and environmental co-benefits.

\section{REDD+ IN INDONESIA}

The development of REDD+ in Indonesia has been in rapid change because it must be in line with the annual meeting of COP of UNFFCCC that comprises many novelties and complexities. It cannot be detached from the COP of UNFCCC that initiated the first idea of reducing emissions from deforestation and forest degradation. The government of Indonesia is aware that REDD+ can bring benefits to Indonesia and become a major participant in REDD+ negotiations.

REDD was initiated in the COP 13 of UNFCCC in 2007, held in Bali, resulting in Bali Action Plan. The conference mainly focused on long term cooperation after the first commitment period of the Kyoto Protocol expired in 2012. Additionally, it also brought the climate change topic, including adaptation decisions, reducing emission from deforestation and degradation, and technology transfer (MRFCJ, 2013).

The conference tried to gather a commitment from all developed and developing countries to reduce GHG. Financing and technology transfer are the main priorities for developed countries because they are expected to increase their effort to cut their emissions significantly and enhance their financial and technological cooperation with developing countries, including protecting the forest. Meanwhile, developing countries are expected to commit to a path of sustainable development by mainstreaming environmental issues into their national development plans, and those countries with forests must preserve and expand them (UNFCCC, 2008).

Besides the urge to follow the Bali Action Plan, the Indonesian government must consider previous laws and regulations regarding the existing environment and forest management to fit COP 13. Previously Indonesia had ratified the Kyoto Protocol through Law Number 17 of 2004 in 2004. In line with that, to actualize the outcome of COP 13, the government made the Ministry of Forestry Regulation Number P.68/Menhut-II/2008, describing the mechanism of demonstration activities (DA) reduction of carbon emissions from deforestation and forest degradation. This regulation was the first step to deliver DA in the REDD framework for the next few 
years. DA points out the importance of collaborative actions between developed and developing countries in implementing REDD, including financial support, capacity building, and technology transfer from developed countries (Ministry of Forestry of the Republic of Indonesia, 2010).

Demonstration activities are essential to establish a basic stock of practical experiences related to REDD+. Despite its essentiality, DA has no fixed definition. However, critical activities for DA include the promotion of more sustainable forest management practices, forest conservation combined with incentive payment schemes, and monitoring systems measuring the change in carbon stocks and fluxes regarding reliable carbon monitoring systems as a critical element of the activities (Kanounnikoff \& Apirak, 2009).

A year after COP 13, COP 14 was held in Poznan. REDD+ was introduced in the 29th Subsidiary Body for Scientific and Technological Advice (SBSTA). In the SBSTA, the REDD+ was introduced as reducing emissions from deforestation and forest degradation in the developing countries with forest conservation, sustainable forestry, and enhancement of carbon stocks (SATGAS REDD+, 2012). In addition, the conference pointed out the importance of technology transfer and financial bodies in REDD. The government started redirecting its forest management to REDD+ to formulate a managing agency for REDD+.

There were two submissions related to REDD+ proposed by Indonesia with neighboring countries in COP 14. The first submission was the partnership document between Indonesia and Australia, suggesting REDD to be part of the mechanism of post-2012 when the Kyoto Protocol expired. Indonesia shared the importance of the policy approach and positive incentives of REDD for Indonesia - Australia partnership that delivered a REDD+ demonstration activity in Kalimantan. The second submission was Indonesia, with nine ASEAN countries proposed the ordinary position paper on REDD. This submission was the first of ASEAN countries on the same page in combating climate change (The Ministry of Forestry Republic of Indonesia, 2008). They declared that the failure of $\mathrm{A} / \mathrm{R}$ CDM
(Afforestation/Reforestation Clean Development Mechanism) should be prevented on REDD+.

In 2009, COP 15 was held in Copenhagen, resulting in the Copenhagen Accord that considered full and effective participation of relevant stakeholders, including indigenous peoples and local communities. It aimed to stabilize gas concentration at a level that would prevent dangerous anthropogenic interference, recognize the scientific view that the increase in global temperature should be below $2^{\circ}$ Celsius, and a long-term cooperative action to combat climate change (UNFCCC, 2010). The Accord also mentions the importance of the communities and indigenous group participation in REDD+, particularly the Measurable, Reportable, Variable (MRV). However, there is no specific measure of reducing $\mathrm{CO} 2$ on the Copenhagen Accord. Also, parties agreed in the final COP decision not to take the Copenhagen Accord and did not adopt it because it was not legally binding (MRFCJ, 2013). The Copenhagen Accord is vital for Indonesia because it focuses on methodology and financing REDD+, which has expanded the technicalities and mechanism of the REDD+ implementation in the next few years.

In 2010, COP 16 UNFCCC took place in Cancun. It focused on the formalization of measures to the Copenhagen Accord, resulting in the Cancun Agreement. The Cancun Agreement adopted REDD+ using the phases approach, including the sub-national activities. The Cancun Agreement points out the methodology and execution of REDD, technology, and mitigation comprehensively. Nevertheless, the financing establishment was saved for the next COP conference.

The Cancun agreement highlights the importance of involving indigenous people and local communities by respecting their rights and knowledge. Embracing their participation means to ensure the conservation of biodiversity and the need for good forest governance. Therefore, REDD+ activities must be undertaken with the full and effective participation of indigenous people and local communities.

The Cancun Agreement is essential for Indonesia to build a REDD+ framework involving all stakeholders, including indigenous people and local communities. 
Indonesia is home to many indigenous people and local communities highly impacted by REDD + activities. The government recognized 1,128 ethnic groups, while the national organization of indigenous people, Aliansi Masyarakat Adat Nusantara (AMAN), estimated that the number of indigenous people in Indonesia was between 50 and 70 million people (International Work Group for Indigenous Affairs, 2018). Before the Cancun Agreement was established, the topic of REDD+ only revolved around methodology and financing, which excluded the indigenous people directly influenced by REDD+. The Cancun Agreement mentions that indigenous people are essential for effective action on all aspects of climate change. It addresses the impacts of REDD+ on people whose life is forest-dependent. The developing countries are necessary to develop and implement their national strategies or action plans of reducing emissions from deforestation and forest degradation regarding land tenure issues, forest governance issues, gender considerations and ensuring the full and effective participation of relevant stakeholders: indigenous people and local communities (UNFCCC, 2010). Therefore, the Cancun Agreement has emphasized that the participation of indigenous people and local communities is essential to achieve success in implementing REDD+.

Indonesia joined COP 17, which took place in Durban in 2011, resulting in the Durban Platform for Enhanced Action. It was considered a turning point in the climate change negotiations because governments recognized the need to draw up the blueprint for a fresh universal, legal agreement to deal with climate change beyond 2020, where all would play their part to the best of their ability and could reap the benefits of success together (UNFCCC, 2011). The Durban Platform for Enhanced Action is a commitment for all parties to see a universal legally binding agreement of climate change no later than 2015, allowing entry into force by 2020.

COP 17 specifically pointed out that reducing emissions required all government levels from the nation, sub-national, and until local to support the REDD+ (UNFCCC, 2011). Recognizing this importance, Indonesia has made action plans involving regional and local government. Indonesia also embraced all stakeholders from the private and non-private sectors. The role of private and non-private sectors in the Paris Agreement has become more critical after the advancements of REDD+ in COP 18 to 21.

COP 18 reached an agreement to extend the life of the Kyoto Protocol, which had ended at the end of 2012. It was also the first time the concept of "loss and damage" was appointed, an agreement in principle that more prosperous nations could be financially responsible to other nations for their failure to reduce carbon emissions. Meanwhile, in COP 19 of 2013 in Warsaw, an agreement was reached that all states would start cutting emissions as soon as possible, but preferably by the first quarter of 2015. COP 20 in Peru aimed to reduce greenhouse gas emissions (GHGs) to limit the global temperature increase to $2^{\circ}$ Celsius above current levels. In this conference, the European Union also aims for a legally binding 40\% drop in emissions by 2030 against carbon output in 1990 as the baseline. COP 21, known as Paris Climate Conference resulting Paris Agreement, promoted regional and international cooperation to mobilize stronger and more ambitious climate action by all parties and non-party stakeholders, including civil society, the private sector, financial institutions, and cities and other subnational authorities, local communities and indigenous people.

In 2016, COP 22 was held in Marrakesh, resulting in Marrakech Action Proclamation for Our Climate and Sustainable Development, and it agreed to implement the Paris Agreement immediately. The Ministry of Environment and Forestry of the Republic of Indonesia stated the role of Indonesia in strengthening global commitment to mitigate climate change through the implementation of the Paris Agreement (Ministry of Environment and Forestry, 2016).

Following the timeline of COP, the development of REDD+ in Indonesia has been strengthened by the government's regulations. In May 2009, the Ministry of Forestry issued Ministerial Regulation Number P.30/Menhut-II/2009 regarding the mechanism of REDD, followed with Ministerial Regulation Number P.36/Menhut-II/2009 regarding the procedures and mechanism of the commercial permit for carbon stocks in production forest and protected forest. At the G20 
Meeting in Pittsburg in 2009, the government also pledged to drastically reduce Indonesia's carbon footprint by voluntarily reducing greenhouse gas emissions by 29 percent using their efforts to 46 percent with international assistance from BAU levels by 2030. By this, Indonesia has committed to engage REDD+ at all levels fully.

\section{IMPLEMENTATION OF REDD + IN INDONESIA}

All REDD+ projects in Indonesia generally focus on the drivers of deforestation and forest degradation. Di Gregorio et al. (2012) mentioned that agriculture, logging, and mining are the main drivers in Indonesia. Agriculture includes extensive scale activities such as oil palm and small-scale activities such as farming and subsistence. The projects carry a heavy burden compared to CDM. Without any specific measurement, REDD+ will be like another CDM, where India and China share over 70 percent of the total CDM projects, with rules that are too complex for many low-income countries to benefit from them (Bleaney et al., 2009). That is why affordable and replicable methods for Monitoring, Reporting and Verification (MRV) are very much necessary. It is also important to note that MRV has a close relation with the environmental damages and disasters caused by human activities (Fitriawan, 2017).

MRV plays a key success in implementing REDD+ projects in Indonesia. One of the instances is in UN-REDD. The government and its collaborating partners brought the first project with three different UN bodies: FAO, UNDP, and UNEP. The main goal is to strengthen consensus and participation from all parties in both regional and national, gain success in MRV, REL, and fair trade within REDD+ frameworks, and build the capacity to implement REDD+ at the regency level.

REDD+ has many funding sources. One of the main reasons is that it is seen as a major opportunity and a low-cost option to limit global warming (Angelsen, 2008). The funding includes public and private sectors, national and international. The mechanisms are also varied from taxes, carbon markets to the auctioning of allowances (Streck \& Parker, 2012). REDD+ is often associated with payments for environmental services (PES) initiatives. ${ }^{1}$
They are considered as a mechanism for reducing carbon emissions. They have become increasingly popular (Sunderland, Blom, \& Murdiyarso, 2010).

At the country level, Norway is the most prominent REDD+ donor (Streck \& Parker, 2012). Simula (2010) and PWC (2011) stated that bilateral country programs and projects currently fund two-thirds of all internationally supported REDD+ activities with multilateral resources making up the remainder.

Having assisted by international funds from many donors such as Norway, regulations and frameworks established regarding forest conservation in Indonesia have been solidified as the basis of REDD+ implementation. After signing the LoI, the evidence is obvious that the Indonesian government issued presidential decree number 19/2010 in September regarding the managing agency to reduce emission from deforestation and degradation of forest and peatlands. The Managing Agency, well known as Satgas REDD+ (REDD+ Task Force), has a primary function to deliver activities related to the implementation of LoI (SATGAS REDD+, 2012). ${ }^{2}$

Additionally, Australia and Indonesia had also strengthened their REDD+ bilateral cooperation in March 2010 through IAFCP (Indonesia - Australia Forest Carbon Partnership). This time Australia contributed AUD 30 million for SFCP (Sumatra Forest Carbon Partnership), while previously in 2007, Australia already launched Kalimantan Forest Carbon Partnership (KFCP) with the same amount of funds (The REDD Desk, 2014). Both are part of IAFCP that aims to test the application of REDD+ in different contexts. Even though they have the same budget, KFCP and SFCP differ in location and forest type. The source of financing REDD+ in Indonesia also comes from Germany. In 2012 Germany committed 27 million euros (\$39 million) for a pilot project demonstrating how the REDD program would work ahead of its implementation in 2012 and continued until 2016 (The Jakarta Globe, 2010).

The REDD+ project has been implemented in the Meru Betiri National Park (MBNP). The MBNP, located in Jember East Java, has become one of the REDD+ pilot projects in Indonesia since 2010, with the duration of the project initially from 2010-2014 (48 months) and 
extended to the first semester of 2015 (52 months). It is the first and only REDD+ project on Java. The location REDD+ in MBNP is $100 \%$ inside the conservation area of the park. It aims to deliver a tropical forest conservation plan as part of REDD+ initiatives (Mahmudah, 2010). REDD+ in MBNP has been run under a public-private partnership from the Indonesian Ministry of Forestry and ITTO with financing from $7 \&$ i Holdings Ltd. ITTO pledged to contribute US $\$ 814,590$, and Indonesia pledged to contribute US\$ 158,798 (ITTO, 2009). In 2011, MBNP succeeded in setting its carbon baseline with a total of 29,690,954.3 tCO2e.

Under public-private partnerships, the implementation of REDD+ in Indonesia is expected to accelerate to achieve the general objectives mandated in the Bali Action Plan and the Copenhagen Accord. One of the mandates is that REDD+ should reflect efforts to reduce emissions and the growing initiatives on conserving and enhancing forests with their values and secluding the local community. The specific objectives of the implementation of REDD+ in MBNP are to improve the livelihood of the local community living inside and in the surrounding the MBNP through the participation to avoid deforestation, degradation, and biodiversity loss

\section{THEORY OF PARTICIPATION}

The participation of all stakeholders is needed to achieve the success of a policy. Therefore, this research used the theory of participation from Choguill. Choguill (1996) starts the ladder with the most community involving rung (1) as the top-down initiatives to the absence of collaboration between government and community (8). Empowerment, partnership, and conciliation are classified as support. Support means that the government gives genuine power with gradations in each rung. Empowerment is the highest rung with full community participation. It may take the form of community members having a majority of seats or genuine specified powers on formal decision-making bodies over a particular project or program involving community participation when municipal authorities are unable or unwilling to undertake improvements themselves (Choguill, 1996).

In empowerment, community members have the responsibility for their improvements. Their initiative for the program determines the outcomes. It is possibly performed with the help of an NGO. Community members need to make an ally with outsiders and the government to give insight and control their improvement.

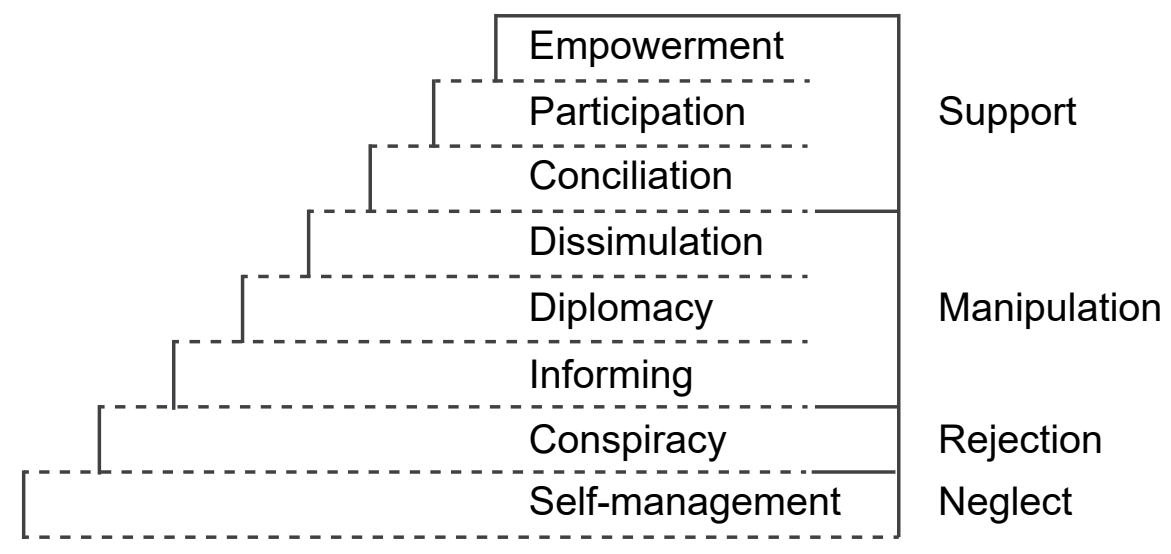

Figure 1. Ladder of Community Participation/Non-participation (Choguill, 1996)

and to develop a credible, measurable, reportable, and verifiable system for monitoring emissions reductions from deforestation and forest degradation and enhancement of forest carbons stocks in MBNP (ITTO, 2009).
Below empowerment is a partnership. At this level, community members and outside decision-makers and planners agree to share planning and decision-making responsibilities about development projects involving community participation through such structures as joint 
policy boards, planning committees and eventually other informal mechanisms for resolving problems and conflicts (Choguill, 1996).

Government still has little power to control the community and program. Community members have the right to have a voice and also the capacity to negotiate. However, with the government providing them assistance, the involvement of the government becomes more intense and more frequent than in empowerment (Choguill, 1996). Conciliation occurs when the government devises solutions ratified by the people. Government has the willingness to appoint a few members from the community as representatives. These representatives can be brought into advisory groups, decision-making bodies, or ad-hoc institutions related to the program. Even though the government considers their opinion, they must accept the decision they cannot change. The decisions come from the powerful and persuasive elite who can run the project with the paternalistic approach (Choguill, 1996). Therefore, conciliation has the least support of three rungs.

At the fourth rung down in the ladder, the government gradually starts to stop supporting the community. People are placed on rubber stamp advisory committees or boards to educate them or, more frequently, engineering their support (Choguill, 1996).

In diplomacy, the government shows a lack of interest, financial support, and competencies in handling the program. The government expects the community to improve themselves with the assistance of NGOs. If there is a good improvement from the process of collaborating between the community and an outside organization, the government may change its attitude, such as providing limited support. The government may conduct several forms of consultation, such as public hearings, neighborhood, and surveys. However, there is no assurance that they will affect the outcome of the program. The community cannot ensure the government that new projects will be implemented. Government has no pledge to take their opinions and concerns about the project into account (Choguill, 1996).

Like any other terms of informing, it consists of a one-way flow of information from officials to the community, their rights, responsibilities and options, without allowance for feedback or negotiation, in projects developed (Choguill, 1996). Informing the government seems to care about the community by educating them about specific programs, but their only purpose is to get the projects done without wanting the community's feedback. It is the reason Choguill (1996) stated that informing is a level of manipulation and constitutes the sixth rung down of the participation ladder.

The seventh rung down the ladder is a conspiracy. Government launches projects or programs to disguise their motives. Choguill (1996) argues that the government rejects helping the poor community they consider as an embarrassment. The government thinks that community members have no competence in the program. Here, no participation in the formal decision-making process is allowed or even considered (Choguill, 1996). Despite knowing what the community needs, the government only cares about launching their projects for their motives. This rung shows rejection from the government to assist the community to improve themselves.

At the bottom, there is self-management. It depicts no community participation because the government has no intention to solve problems that the community bears. Government has no program and plan to improve life within the community. Members of the community must plan the programs and bring improvements to their neighborhood. It includes controlling the projects, which is not always bringing a successful outcome. In the absence of government involvement, some NGOs usually provide assistance such as independent financial support that can positively affect the outcome of the community's program. By having extensive involvement from NGOs, the community can live up to their program, replacing the government's role. In contrast to empowerment, self-management implies situations that result from a lack of governmental interest in or even opposition to the poor people's demands (Choguill, 1996).

This theory of participation considers NGOs as external support that can facilitate the outcome of the community effort. Also, in the ladder of community participation, community mutual help is identified as a fundamental component. 
REDD+ involves government, community, and outside organizations such as NGOs. It also comprises many complexities within the policy and implementation. Essentially local community in REDD+ is expected to demonstrate self-help. Based on this reasoning, Choguill's ladder of community participation is suitable for this research.

\section{RESEARCH METHOD}

This research used a single case study and benefitted from qualitative and quantitative methods employing a questionnaire, an in-depth interview, and a literature study. The location of the research was in the villages inside and surrounding the MBNP. The respondents for the questionnaire were gathered from five areas in three villages participating in REDD+: Sarongan, Andongrejo, and Curahnongko using stratified random sampling with the proportional method of choosing the family heads. By calculating the number of the heads of family members in three villages (4518 family heads), the number of samples was 100 with proportion sample divided as follows: 38 from Curahnongko, 29 from Andongrejo, and 33 from Sarongan. The criteria of respondents were the single head of the family, living in the area of research, and willing to be a respondent.

The ladder participation level was identified using Choguill's participation theory. Choguill (1996) starts the participation ladder with the most community involving rung (1) as the top-down initiatives to the absence of collaboration between government and community (8). Empowerment, partnership, and conciliation are classified as support. Support means the government gives genuine power with gradations in each rung. Empowerment is the highest rung with full community participation. The partnership means community members and outside decision-makers and planners agree to share planning and decision-making responsibilities about development projects involving community participation through such structures as joint policy boards, planning committees and eventually other informal mechanisms for resolving problems and conflicts (Choguill, 1996). This participation level occurs when the government devises solutions accepted by the people. Government has the willingness to appoint a few members from the community as representatives. These representatives can be brought into advisory groups, decision-making bodies, or ad-hoc institutions related to the program. Even though the government considers their opinion, they must accept the decision they cannot change. The decisions come from a powerful and persuasive elite who has the authority to run the project with the paternalistic approach (Choguill, 1996). It is the reason conciliation has the least support of three rungs.

To quantify the participation level, variables were made according to Choguill's participation theory. The variables derived are:

(1) attendance,

(2) frequency,

(3) activeness in delivering,

(4) participation in decision making,

(5) local community perceptions about budget allocation,

(6) organizer competence,

(7) NGOs' involvement.

The assessment used eight options for each variable. Each variable was weighted from score 1 to 8 . Taking 100 respondents and variables with eight options, the questionnaire has a maximum score of 800 and a minimum score of 100. Each option has different quantifications adjusted to the 8 levels of community participation. At the lowest, the score is 1 , and at the highest, the score is 8 . This score also depicts that the higher value means the higher level. Therefore, Choguill's level of community participation can be measured as follows:

(1) 712.6 - 800 (Empowerment),

(2) $626-712.5$ (Partnership),

(3) 537.6 - 625 (Conciliation),

(4) $451-537.5$ (Dissimulation),

(5) 362.6 - 450 (Diplomacy),

(6) 276 - 362.5 (Informing),

(7) $187.6-275$ (Conspiracy),

(8) 100 - 187.5 (Self-management). 


\section{RESULT AND ANALYSIS}

Local communities around the MBNP area are divided into four subdistricts into two administrative regions of Jember and Banyuwangi, consisting of 12 villages Andongrejo, Curahnongko, Wonoasri, Sanenrejo, Curahtakir, Mulyorejo, Pace, Sidomulya, Sarongan, Kandangan, Kebonrejo dan Kalibaru Kulon. Some areas of Curahnongko and Sarongan are located within MBNP. According to MBNP villages monograph data (2015), the total population of twelve villages around MBNP reached 103,311 people. The most densely populated village was Sanenrejo village with a population density reaching 852 inhabitants $/ \mathrm{km}$, while the village with the lowest population density was Andongrejo with only 21 inhabitants $/ \mathrm{km}$. Most of the population living around the TNMB area were Javanese and Madurese.
Rajegwesi and Sukamade (Sarongan Village), livelihoods starting to be sought were related to attractions such as tour guides, souvenir sellers, and tour boat services. The increasing number of tourists visited Bandealit, Rajegwesi, and Teluk Hijau beaches inside the MBNP area.

The buffer zone villages of the MBNP area had a weak economy with an average income below IDR $1,500,000.00$ (US\$107) per month. The highest number of poor people was in Andongrejo, reaching 73.2\%, in Sarongan, reaching $38.17 \%$ and in Curahnongko, reaching 32.88\% (Meru Betiri National Park Office, 2015 ). The poverty that hit Andongrejo village was due to the narrow agricultural land and the buffer zone forest area in this village, which was only $2.73 \%$ of the total agricultural land of MBNP and $5.89 \%$ of the total buffer

Table 1. Community Involvement

\begin{tabular}{|c|c|c|c|}
\hline Region & Yes $(\%)$ & No (\%) & Total (\%) \\
\hline Sarongan & 14 & 3 & 17 \\
\hline Rajegwesi & 21 & 2 & 23 \\
\hline Curahnongko & 28 & 2 & 30 \\
\hline Bandealit & 8 & 1 & 9 \\
\hline Andongrejo & 12 & 9 & 21 \\
\hline Total & 83 & 17 & 100 \\
\hline
\end{tabular}

Note. Compiled by author

Most of the inhabitants in MBNP villages had livelihoods as farmers/landowners and farmer/laborers, reaching $79 \%$ of the population. The agricultural system, in general, used a rainfed system because the irrigation facilities were rare. Although not many, there were also inhabitants working as traders, casual laborers, and fishers. The inhabitants of the villages of Curahnongko, Sarongan, and Andongrejo had the characteristics of an agrarian village so that the majority of its inhabitants worked in the agricultural sector. In addition, there were several other livelihoods, such as seasonal fishermen or anglers living around the coast of Bandealit and Sukamade in Sarongan Village. Furthermore, in zone forest of MBNP. It poses a threat to encroachment and land clearing in the MBNP conservation area. The questionnaire revealed that $83 \%$ of respondents have been involved in the REDD+ program, while $17 \%$ have never been involved. The frequency distribution of community involvement is presented in Table 1:

The table above shows that Curahnongko is the village with most residents attending the REDD+ program. It shows that the level of community participation is higher than in other villages. REDD+ activities involving the community in Curahnongko show better acceptance of its members than any other region. Therefore REDD+ activities have a continuation to be conducted more 
frequently in this region. Furthermore, Curahnongko is one of the villages adjacent to the national park.

Although feeling unfamiliar with the terminology of REDD+, the community has the attention for programs related to REDD+. It is consistent with results of interviewing informants and respondents, stating that the community appreciated the purpose of the activity so that the substance within REDD+ has been understood by members of the community involved in REDD+. Moreover, $41 \%$ of respondents expressed their understanding of the conservation, and empowerment also increased after following the activities of REDD+ that began in 2010. In addition, $83 \%$ of respondents who followed community empowerment and protection of forests (included in REDD+) considered REDD+ activities very important for their national park knowledge. While $17 \%$ of respondents stated that they were not involved in REDD+ because there was no information and socialization, they preferred working to meet their daily needs because they did not know the benefits and importance of REDD+. between joining REDD+ programs and working. They chose REDD+ activities even though the organizer did not provide money as a direct incentive. In addition, only $2 \%$ of respondents contributed money for unprecedented events such as facilitating informal meetings by providing a place, snacks, foods, or drinks. At this stage, all respondents stated that their contributions were significant in the success of the program and the optimization of the results for themselves.

Based on the levels identified on each variable, the participation level of the community is demonstrated in Table 2.

By taking the highest point at each level, the average level of local community participation is conciliation with a score of 601.8. At this stage, the local community is stepping at the highest spectrum participation: support, leaving the rungs of manipulation, rejection, and neglect.

Conciliation is the third rung in the spectrum of support. It indicates that the local community and the government are at an early stage to support each other and be aware of each other's interests. However, there is still a

Table 2. Community Participation Result

\begin{tabular}{lcc}
\hline \multicolumn{1}{c}{ Variables } & Score & Level \\
\hline Attendance & 536 & Conciliation \\
\hline Frequency & 328 & Simulation \\
\hline Activeness in Delivering Ideas & 331 & Information \\
\hline Participation in Decision Making & 401 & Diplomacy \\
\hline Perception of Budget Allocation & 411 & Diplomacy \\
\hline Organizer's Competence & 657 & Partnership \\
\hline NGOs involved & 325 & Conciliation \\
\hline
\end{tabular}

Note. Compiled by author

Of the $83 \%$ of respondents involved in REDD+ activities at the implementation stage, all of them donated material and nonmaterial. Ideas and suggestions are the forms they contributed the most. They also allocated their time to join the training or workshop related to REDD+ programs. It created a tradeoff dominant control from the government, especially in decision-making. The dominance of the government in decision-making is a form of a paternalistic approach to identify the needs of the community through consultation without involving them in it. Through this approach, the local community accepts any decision 
made by the government as long as their interests are met. hold essential positions such as village leaders or elderly

The interview with officers of MBNP showed that REDD+ has economic and environmental advantages for the long term. There is mutual support between local government, local communities, and the organizers or outsiders, in this case, the ITTO. Compared with the REDD+ project in Central Kalimantan, participation was difficult to identify because there was a negative perception of REDD+. In Central Kalimantan, communities and local governments involved had a strong notion that REDD+ only benefited outsiders alone, and they also assumed that REDD+ activities only to the extent the funding of extensive and merely project activities involving companies or institutions with large capital (Affif, Kussarianto, \& Ibie, 2011). It happened because local government and people were not involved intensively in collaborative REDD + projects affecting people's participation.

The community in Meru Bertiri was at the early stage of conciliation. There were still problems such as unfair procedures to choose representatives and the limitation of information dissemination. Choguill (1996) argued that these characters are still part of dissimulation and manipulation mixed in the early stage of conciliation, including the motive to attend only for money or incentives. However, the interview with officers of MBNP rejected the latter. There was no fresh money as incentives from the government. It is also supported by an interview with community members saying that fresh money was not the right form of assistance.

The role of public figures within the community is perceived as highly important. Public figures are defined as people with wide influence in the area. They usually and respected people. They have a strong influence to engage community members to attend the programs. Even though the dissemination of information is limited, it has become more efficient through these public figures. It has been observed through the activity of a farming group in Andongrejo, where the leader is a public figure. The leader was informed first about attending the REDD+ program and then informing his group of ten persons to join the activity. The result was that 8 out of 10 joined the program. The leader was informed first about attending the REDD+ program and then informing his group of ten persons to join the activity. The result was that 8 out of 10 joined the program.

Even though the participation reached conciliation, illegal logging is still happening related to the lack of law enforcement in the MBNP region. A total of $27 \%$ of respondents stated that weak law enforcement had been hampering community participation. In this case, the respondents argued that participation would lose its meaning as long as the ignorance of community members who conducted the illegal logging continued.

Although not directly related to community participation in REDD+, rampant illegal logging and weak law enforcement became major challenges to the success of community participation. Illegal logging activities happened in conservation areas, while weak law enforcement caused many illegal loggers to take advantage of the forest area for the long term. It was also associated with the limited number of forest rangers in MBNP. The participation of local communities in REDD+ did not reduce illegal logging cases significantly. In 2014, the number of illegal logging cases in MBNP

\section{Illegal Logging in Meru Betiri}

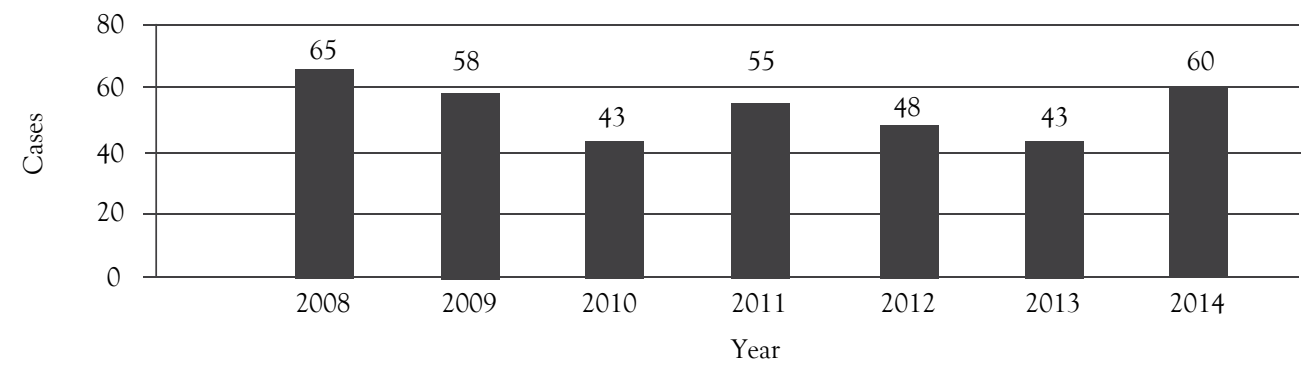

Figure 2. Number of illegal logging cases in MBNP 2008-2014 (MBNP, 2014) 
increased from 43 to 60 when the REDD+ program was running. It means that community participation in REDD+ is not always linear in forest encroachment and illegal logging. The number of cases of illegal logging can be seen in Figure 2. have local knowledge, but some communities have cultures to explore the forests since the previous generation. It causes environmental awareness varies from one community to another.

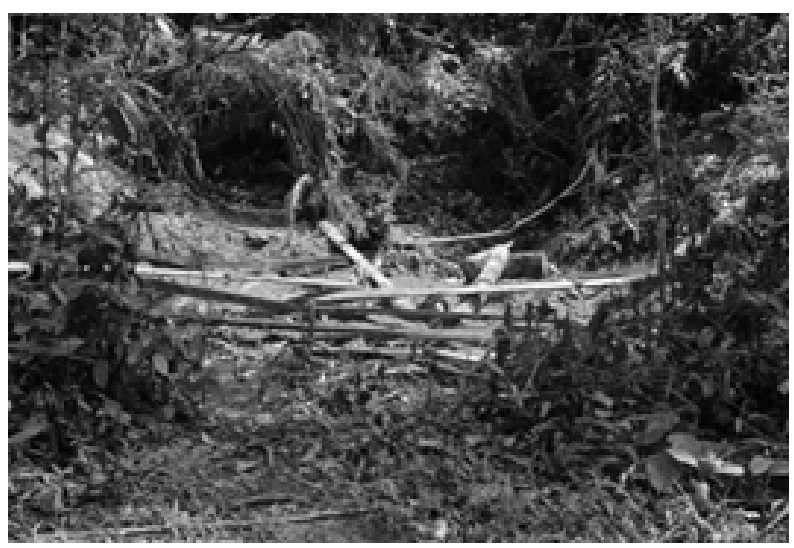

Figure 3. Illegal Logging in the MBNP area (author's work)

The community perceived illegal logging as something extremely damaging that had been conducted by the outsiders with the help of locals. Most of the time, the community knew people involved in illegal logging but had no power to act upon it. Interviews with officers and community members stated that the pressure of illegal logging on the forest had come from villages directly adjacent to the national park. One of them was the Andongrejo Village, the main entrance to the national park area.

From year to year, the MBNP region receives tremendous pressure from encroachment, and illegal logging carried out by communities around the region. World Bank (Angelsen \& Kaimowitz, 1999) also mentioned that one-third of the forests in developing countries have been inhabited by local communities depending on the forest. It makes the number of communities have a much lower income than the forest communities in developed countries. Some communities

\section{CONCLUSION}

Conciliation with the least degree of support in the implementation of REDD+ in MBNP means that government appoints a few members from the community as representatives that can be brought into advisory groups, decision-making bodies, or ad-hoc institutions related to the program. Even though the government considers their opinion, they have to accept the decision they cannot change. This conciliation as the level of community participation contributed to reach the goals of REDD+ programs proven by the material and nonmaterial support provided by the community. However, the numerous cases of illegal logging have been a major challenge found to the success of the program. It is dominated by weak law enforcement. It causes the number of illegal logging cases has been increasing these five past years. Community participation cannot succeed when illegal logging still proceeds. Therefore, it also affects the objectives of REDD+ in MBNP. 


\section{ENDNOTE}

PES is a voluntary transaction where a well-defined ES (or a land-use likely to secure that service) is being 'bought' by a (minimum one) ES buyer from a (minimum one) ES provider if and only if the ES provider secures ES provision (conditionality) (Wunder, 2005).

2 The period of SATGAS REDD + depends on presidential decree. At first it was prolonged until December 2012 but then its objective to deliver the implementation of Lol hasn't been accomplished so the latest period of Task Force is by the end of June 2013

\section{REFERENCE}

Affif, S., Kussarianto, \& Ibie, B. F. (2011). Study of Stakeholders Participation in REDD + in Central Kalimantan. Pontianak: Kemitraan.

Alexander, S. (2011). Opportunities and Challenges for Ecological Restoration Within REDD+. Restoration Ecology, 19(06), 683-689.

Angelsen, A. \&. (1999). Rethinking the Causes of Deforestation: Lessons from Economic Models. World Bank Research Observer, 14(1), 73-98.

Angelsen, A. (2008). REDD Models and Baselines. International Forestry Review, 10(3), 465-475.

Askham, B. (2010). REDD pilot projects in Indonesia. Retrieved January 11, 2019, from from http://www.ecosmaga zine.com/? paper $=\mathrm{EC} 10048$

Awono, A., Somorin, O. A., Atyi, R. E., \& Levang, P. (2013). Tenure and participation in local REDD+ projects: Insights from Southern Cameroon. Environmental Science \& Policy, 35, 76-86.

BAPPENAS. (2010). National REDD + Strategy: Revised Edition. Jakarta: BAPPENAS.

Bleaney, A., Vickers, V., \& Peskett, L. (2009). REDD+ in Nepal: putting community forestry centre stage. Bangkok: REDD+ Net.

Boissière, M., Herold, M., Atmadja, S., \& Sheil, D. (2017). The feasibility of local participation in Measuring, Reporting and Verification (PMRV) for REDD+. PLOS ONE, 12(5), e0176897. doi:https://doi.org/10.1371/jour nal.pone.0176897

Bong, I. W., Felker, M. E., \& Maryudi, A. (2016). How Are Local People Driving and Affected by Forest Cover Change? Opportunities for Local Participation in REDD+ Measurement, Reporting and Verification. PLOS ONE, 11(11). doi:10.1371/journal

Casse, T., Milhøj, A., Nielsen, M. R., Meilby, H., \& Rochmayanto, Y. (2019). Lost in Implementation? REDD + Country Readiness Experiences in Indonesia and Vietnam. Climate and Development, 11(9), 799-811. doi:https:// doi.org/10.1080/1756552

Choguill, M. B. (1996). A Ladder of Community Participation for Underdeveloped Countries. Habitat Intl, 20(3), 431-444.

CIFOR. (). (2010). Simply REDD: CIFOR's Guide to Forest, Climate Change, and REDD. Bogor: CIFOR.

Cromberg, M., Duchelle, A. E., \& Rocha, I. O. (2014). Local Participation in REDD+: Lessons from the Eastern Brazilian Amazon. Forests, 2014(5), 579-598. doi:10.3390/ 5040579

Di Gregorio, M., Brockhaus, M., Cronin, T., \& Muharrom, E.
(2012). Politics and Power in National REDD + Policy Processes. In Analysing REDD+: Challenges and Choices (pp. 69-90). Bogor: CIFOR

Ekawati, S., Subarudi., Budiningsih, K., Sari, G. K., \& Muttaqin, M. Z. (2019). Policies affecting the implementation of REDD+ in Indonesia (cases in Papua, Riau, and Central Kalimantan). Forest Policy and Economics, 108, 1-15 doi:doi.org/10.1016/j.forpol.201

Enrici, A. M., \& Hubacek, K. (2018). Challenges for REDD+ in Indonesia: a case study of three project sites. Ecology and Society, 23(2), 7. doi:doi.org/10.5751/ES-09805-230207

Erbaugh, J., Nurrochmat, D., \& Purnomo, H. (2017). Regulation, formalization, and smallholder timber production in northern Central Java, Indonesia. Agroforest System, 91, 867-880. doi: doi.org/10.1007/s10457-016-0037-6

Fitriawan, R. A. (2017). Scientific Journalism and Early Warning System in Indonesia. Journalism Studies, 1(1), 41-59.

Forsyth, T. (2009). Multilevel, Multiactor Governance in REDD+: Participation, Integration, and Coordination. In A. Angelsen, M. Brockhaus, M. Kanninen, W. D. Sunderlin, \& S. Wertz-Kanounnikoff (Eds.), Realising REDD+: National Strategy and Policy Options (p. 113). Bogor: CIFOR.

Hein, J. I. (2019). Political Ecology of REDD + in Indonesia: Agrarian Conflicts and Forest Carbon. New York: Routledge.

ITTO. (2009). Tropical Forest Conservation for Reducing Emissions From Deforestation and Forest Degradation and Enhancing Carbon Stocks in Meru Betiri National Park, Indonesia. Tokyo: ITTO.

Kanounnikoff, S. W., \& Apirak, M. K. (2009). Emerging REDD+: A preliminary survey of demonstration and readiness activities. Bogor: CIFOR.

Lubowski, R. N., \& Rose, S. (2013). The Potential for REDD+: Key Economic Modeling Insights and Issues. Review of Environmental Economics and Policy, 7(1), 67-90.

Lyster, R. (2013). International Legal Framework for REDD+: Ensuring the Legitimacy. In R. Lyster, C. MacKenzie, \& C. McDermott (Eds.), Law, Tropical Forest, and Carbon: The Case of REDD+ (pp. 3-25). Cambridge:: Cambridge University Press

Mahmudah, L. (2010, July 30). Meru Betiri park prepares to host REDD Pilot project. Retrieved January 10, 2019, from from The Jakarta Post: http://www.thejakarta post.com/news/2010/07/30/meru-betiri-park-pre pares-host-redd-pilot-project.html

Marklund, L., \& Schoene, D. (2006). Global assessment of growing stock, biomass and carbon stock. Rome: Forest Resource Assessment Program.

Meru Betiri National Park Office. (2015). The Monograph of Meru Betiri National Park. Jember: Meru Betiri National Park Office.

Miettinen, J., Shi, C., \& Liew, S. C. (2011). Deforestation Rates in Insular South East Asia between 2000 and 2010. Global Change Biology, 17, 2261-2270.

Ministry of Forestry of the Republic of Indonesia. (2010). Strategy REDD-Indonesia: Readiness Phase 2010-2012 \& the implementation progress. Jakarta: Indonesian Ministry of Forestry.

Ministry of Forestry of the Republic of Indonesia. (2011). The Implementation of REDD + in Indonesia. Retrieved April 11, 
2014, from from http://ditjenppi.menlhk.go.id/ber ita-ppi/33-beranda/1804-faq.html

Ministry of Forestry of the Republic of Indonesia. (2016, November 29). Indonesia joined COP 22. Retrieved January 10, 2019, from from Ditjen PPI: http://ditjenppi.menlhk.go.id/ber ita-ppi/2795-hasil-menggembirakan-keikutsertaan-indone sia-di-perundingan-cop22.html

Ministry of the Forestry Republic of Indonesia. (2008). Indonesia Discusses REDD at COP 14 in Poznan. Jakarta: The Ministry of the Forestry Republic of Indonesia.

MRFCJ. (2013). The Mary Robinson Foundation Climate Justice: Our Work. Retrieved April 9, 2014, from The Mary Robinson Foundation Climate Justice: http://www.mrfc j.org/our-work/unfccc/cop-timeline.html

PWC. (2011). Funding for Forests: UK Government Support for $R E D D+$. London: Climate Focus \& International Union for Conservation of Nature.

SATGAS REDD+. (2012). Strategi Nasional REDD+. Jakarta: SATGAS REDD + Indonesia.

Simula, M. (2010, December 30). Analysis of REDD+: financing gaps and overlaps. Retrieved January 9, 2019, from from http://reddpluspartner ship.org/25159-09eb378a8444ec149e8ab32e2f5671b11. pdf

Streck, C., \& Parker, C. (2012). Financing REDD+. In Analysing REDD+: Challenges \& Choices (pp. 111-127).

Sunderland, T., Blom, B., \& Murdiyarso, D. (2010). Getting REDD to work locally: lessons learned from integrated. Environmental \& Science Journal, 1-9.

The Jakarta Globe. (2010, January 6). The Jakarta Globe: Archive: REDD+. Retrieved January 11, 2019, from from The Jakarta Globe: http://www.thejakartaglobe.com/archive/germa ny-pledges-39m-for-redd-pilot-project/

The REDD Desk. (2014). REDD Countries: Redd desk Initiatives. Retrieved January 9, 2019, from from http://thered ddesk.org/countries/initiatives/indonesia-australia-for est-carbon-partnership

UNFCCC . (2010). Report of COP 15 in Copenhagen. Bonn: UNFCCC.

UNFCCC. (2008). Report of the Conference of the Parties on its thirteenth session. Bali: UNFCCC.

UNFCCC. (2010). The Cancun Agreements: Outcome of the work of the Ad Hoc Working Group on Long-term Cooperative Action under the Convention. Cancun: UNFCCC.

UNFCCC. (2011). UNFCCC: Durban outcomes. Retrieved January 9, 2019, from from United Nations Climate Change: http://un fccc.int/key_steps/durban_outcomes/items/6825.php 